\title{
Pengaruh Karakteristik Personal dan Karakteristik Pekerjaan terhadap Komitmen Organisasional Perawat
}

\author{
Wiwit Ekayanti \\ Susi Widjajani \\ Budiyanto \\ Manajemen, Universitas Muhammadiyah Purworejo, Indonesia \\ Korespondensi penulis: susiwijayani@gmail.com
}

\begin{abstract}
This study aims to examine the effect of personal characteristics and job characteristics on organizational commitment of hospital nurses. Employee organizational commitment can be influenced by many factors, including personal characteristics and job characteristics. They are the factors form the initial organizational commitment that can affect the ups and downs of employee organizational commitment. The population in this study were hospital nurses in Gombong, Indonesia and the sample of this study was 75 respondents taken by a simple random sampling technique. The data collection technique in this study used a questionnaire with a Likert scale. The main instrument used to obtain data is arranged systematically containing several statements given to respondents who have met the requirements for validity and reliability. Data analysis used multiple linear regression and the hypothesis testing analysis applied partial significance test. The results showed a positive and significant influence of personal characteristics and job characteristics partially on organizational commitment. The implications of the results of this study can be applied in hospitals to build the commitment of nurses through job characteristics and personal characteristics. Further research should use other independent variables outside of this study with a larger number of respondents.
\end{abstract}

Keywords: Personal characteristics, job characteristics, organizational commitment.

Abstrak: Penelitian ini bertujuan untuk menguji pengaruh karakteristik personal dan
karakteristik pekerjaan terhadap komitmen organisasional perawat rumah sakit. Komit-
men organisasional karyawan dapat dipengaruhi oleh banyak faktor, termasuk karakte-
ristik personal dan karakteristik pekerjaan. Karakteristik personal dan karakteristik
pekerjaan merupakan faktor pembentuk komitmen organisasional awal yang dapat
mempengaruhi naik turunnya komitmen organisasional karyawan. Populasi dalam pene-
litian ini adalah seluruh perawat rumah sakit di Gombong, Indonesia dan sampel dalam
penelitian ini berjumlah 75 responden yang diambil dengan teknik simple random
sampling. Teknik pengumpulan data menggunakan kuesioner dengan skala Likert.
Instrumen utama yang digunakan untuk memperoleh data disusun secara siste-matis
berisi beberapa pernyataan yang diberikan kepada responden yang telah meme-nuhi 
persyaratan validitas dan reliabilitas. Analisis data menggunakan regresi linier berganda dan pengujian hipotesis menggunakan uji signifikansi parsial. Hasil penelitian ini menunjukkan adanya pengaruh positif dan signifikan variabel karakteristik personal dan karakteristik pekerjaan secara parsial terhadap komitmen organisasional perawat. Implikasi hasil penelitian ini dapat diterapkan di rumah sakit untuk membangun komitmen organisasional perawat melalui variabel karakteristik pekerjaan dan karakteristik personal. Penelitian lebih lanjut disarankan untuk menggunakan variabel independen lain di luar penelitian ini dengan jumlah responden yang lebih besar.

Kata kunci: Karakteristik personal, karakteristik pekerjaan, komitmen organisasional.

Article Info:

Received: October 19, $2018 \quad$ Accepted: April 18, $2019 \quad$ Available Online: May 8, 2019

DOI: http://dx.doi.org/10.30588/jmp.v8i2.415

\section{LATAR BELAKANG}

Bagian utama dari pelayanan kesehatan di rumah sakit yang diberikan kepada pasien adalah pelayanan keperawatan. Jumlah penyerapan tenaga perawat cukup besar, yaitu rata-rata berkisar antara 60\% sampai dengan 65\% dari keseluruhan tenaga kerja yang ada di sebuah rumah sakit. Pelayanan kesehatan diberikan oleh tenaga perawat kepada pasien secara terus menerus dan konsisten secara nonstop selama 24 jam. Mengingat peran tenaga perawat yang begitu besar dalam memberikan pelayanan kesehatan, penting bagi para pengambil kebijakan di rumah sakit untuk memberikan perhatian yang lebih terhadap hal-hal yang mempengaruhi pekerjaan perawat.

Tingkat kepercayaan masyarakat terhadap pelayanan kesehatan di rumah sakit akan meningkat, jika tenaga perawat mampu menunjukkan hasil kerja yang baik. Perawat akan menunjukkan hasil kerja yang baik, jika mereka memiliki komitmen yang tinggi terhadap organisasinya. Shuck dan Wollard (2010, dalam Bakibinga, 2012) mendefinisikan komitmen organisasional sebagai kognisi personal karyawan, faktor emosional, dan perilaku yang mengarah pada tujuan organisasi. Sikap percaya terhadap nilai-nilai organisasi, berusaha sebaik mungkin demi kepentingan organisasi, dan memiliki tekad untuk tetap menjadi bagian organisasi merupakan cerminan sikap dari adanya rasa komitmen organisasional yang tinggi (Steers, 1985 dalam Triatna, 2015).

Komitmen organisasional yang ditunjukkan oleh perawat selama ini relatif masih rendah. Data menunjukkan bahwa $76 \%$ komitmen perawat di Indonesia masih rendah (Rahayuningsih, 2004 dalam Mulyono, 2010). Komitmen organisasional perawat yang rendah akan memunculkan kerugian bagi organisasi. Kerugian yang dimaksud antara lain pengeluaran organisasi yang meningkat dan perawatan pasien yang terputus (Shields \& Ward, 2001 dalam Lee, Chitpakdee, \& Chontawan, 2011), kepuasan dan keselamatan kerja bagi perawat, dan tenaga kesehatan lainnya akan terdampak negatif, serta dapat mempengaruhi persepsi pelanggan terhadap kualitas pelayanan yang diakibatkan karena adanya penurunan kepuasan dan loyalitas pelanggan.

Bukan hal mudah untuk membangun komitmen organisasional perawat. Upaya tersebut membutuhkan waktu lama dengan tingkat kesulitan tertentu. Perlu adanya kepercayaan terhadap organisasi agar komitmen organisasional dapat terbangun (Payne, 
Huffman, \& Tremble-Jr, 2002, dalam Mulyono, 2010; Chen et al., 2015). Visi dan misi individu harus sejalan dengan visi dan misi organisasi agar kepercayaan perawat terhadap organisasi tercapai. Identifikasi individu yang seperti ini akan meningkatkan motivasi dalam diri perawat dan dapat mendorong kepuasan kerjanya, sehingga dapat berpengaruh positif terhadap komitmen organisasional apabila mereka diberi kesempatan untuk mengembangkan diri (Mulyono, 2010). Identifikasi individu yang kuat akan menginternalisasi nilai organisasi, yang pada gilirannya dapat meningkatkan keterlibatan karyawan untuk mencapai tujuan organisasi (Robbins \& Judge, 2014:92).

Karakteristik personal setiap manusia berbeda-beda antara satu dengan yang lain. Karakteristik merupakan ciri atau kemampuan untuk memperbaiki kualitas hidup (Kamus Besar Bahasa Indonesia/KBBI). Komitmen organisasional disebabkan salah satunya oleh karakteristik personal (Luthan, 2015). Variabel personal yang memiliki keterlibatan adalah usia dan masa kerja, tingkat pendidikan, jenis kelamin, dan status perkawinan. Dalam upaya memperoleh karakteristik personal karyawan yang baik sesuai dengan kebutuhan organisasi, perusahaan menuntut setiap karyawan agar memiliki komitmen yang tinggi dalam bekerja. Menurut Siswanto (2013), seorang individu yang memiliki kinerja dan komitmen yang tinggi dalam menyelesaikan tugasnya di perusahaan sesuai dengan tanggung jawab yang diberikan kepadanya dapat ditunjukkan dengan beberapa kriteria karyawan, seperti kesetiaan, tanggung jawab, inisiatif, dan ketepatan waktu dalam setiap pekerjaan yang dilakukannya.

Selain karakteristik personal, faktor lain yang mempengaruhi komitmen organisasional adalah karakteristik pekerjaan. Karakteristik pekerjaan adalah sebuah pendekatan dalam merancang pekerjaan yang menunjukkan bagaimana pekerjaan didiskripsikan ke dalam lima dimensi inti, yaitu: keanekaragaman ketrampilan, identitas tugas, arti tugas, otonomi, dan umpan balik (Robbins \& Judge, 2014:268). Keberhasilan perusahaan dalam penentuan job description yang jelas pada karyawan dan sesuai kemampuan akan memberikan dampak yang baik, sehingga karyawan memiliki komitmen tinggi terhadap perusahaan dan memberikan kontribusi yang efektif. Komitmen organisasional dipengaruhi oleh karakteristik pekerjaan yang meliputi aspek-aspek tantangan, lingkup jabatan, konflik peran, dan ketidakjelasan peran. Komitmen pekerjaan seseorang akan meningkat seiring dengan meningkatnya tantangan dalam pekerjaannya. Konflik juga akan muncul apabila tidak adanya kejelasan peran pekerja, sehingga komitmen organisasional dapat menurun.

Peran tenaga kesehatan maupun tenaga non-kesehatan di rumah sakit sangat ditentukan oleh kualitas pelayanan kesehatan yang mereka lakukan (Azwar, 2011:46). Salah satu sumber daya manusia yang berkontribusi besar dalam meningkatkan mutu pelayanan kesehatan di rumah sakit adalah perawat. Pelayanan dalam pekerjaan perawat dituntut penuh setiap harinya, sehingga perlu adanya pembagian waktu kerja. Menurut Budiono (2016:138), komitmen organisasional pada perawat merupakan hal penting yang perlu diperhatikan apabila rumah sakit ingin memberikan kualitas pelayanan kesehatan yang baik, serta dapt tercapainya tujuan rumah sakit. Dalam melakukan pelayanan keperawatan yang berkualitas sesuai dengan standar dan etika keperawatan, komitmen yang tinggi sangat dibutuhkan perawat. Pelayanan keperawatan merupakan proses atau rangkaian kegiatan pada praktik keperawatan baik secara langsung maupun tidak langsung yang diberikan pada pasien. Hal tersebut dapat tercapai jika komitmen organisasional dapat diperoleh dan didukung dengan adanya penerapan karakteristik personal dan karakteristik pekerjaan dengan baik. 
Rendahnya komitmen organisasional perawat dapat diindikasikan dengan tingginya turnover rate perawat (Muliana, 2013), tingginya kecenderungan untuk keluar (turnover intention) (Siregar, 2015), tingginya job dissatisfaction, keterlambatan kehadiran perawat di rumah sakit (Yanidrawati et al. 2011), dan adanya fenomena motivasi dan disiplin kerja perawat yang kurang baik (Widyani, 2014). Untuk menekan potensi hal-hal tersebut, maka rumah sakit perlu memperhatikan berbagai aspek karakteristik personal dan karakteristik pekerjaan demi peningkatan komitmen organisasional karyawan. Oleh karena itu, penelitian ini bertujuan untuk menguji keterkaitan karakteristik pekerjaan dan karakteristik personal terhadap komitmen organisasional perawat.

\section{KAJIAN TEORITIS}

\section{Komitmen Organisasi}

Komitmen pada dasarnya merupakan rasa keterikatan seorang karyawan terhadap organisasinya. Pengertian komitmen karyawan sama artinya dengan pengertian komitmen organisasional, karena secara makna komitmen diartikan sebagai tingkat kepercayaan dan penerimaan seorang karyawan terhadap tujuan organisasi dan mempunyai keinginan untuk tetap ada di dalam organisasi tersebut. Komitmen organisasional merupakan cerminan dari individu yang dengan suka rela memberikan kontribusi untuk kesejahteraan organisasi secara aktif melebihi kesetiaan pasif terhadap organisasi (Mowdey et al., 1979). Komitmen menekankan keyakinan pada organisasi, termasuk tujuan dan nilai yang dianutnya.

Komitmen organisasional pada perawat merupakan hal penting yang perlu diperhatikan apabila rumah sakit ingin memberikan kualitas pelayanan kesehatan yang baik, serta dapat tercapainya tujuan organisasi. Dalam memberikan pelayanan keperawatan yang berkualitas dan sesuai standar keperawatan profesional, perawat dituntut untuk memiliki komitmen yang tinggi. Pelayanan asuhan keperawatan merupakan proses atau rangkaian kegiatan pada praktik keperawatan baik secara langsung maupun tidak langsung yang diberikan pada pasien (Budiono, 2016: 138).

Menurut Mowdey et al. (1979), proses terjadinya komitmen organisasional pada kayawan berbeda-beda. Faktor-faktor yang berpengaruh terhadap komitmen karyawan pada organisasi meliputi tiga faktor, yaitu: Pertama, karakteristik personal meliputi ciriciri kepribadian tertentu, usia dan masa kerja, tingkat pendidikan, jenis kelamin, dan status pernikahan. Kedua, harapan-harapan pada karyawan, yaitu menyangkut peran lingkungan kerja, kesempatan untuk mengembangkan ketrampilan atau pengetahuan, dan karier. Ketiga, karakteristik pekerjaan yang meliputi lingkup jabatan, tantangan dalam pekerjaan, konflik peran, dan tingkat kesulitan dalam pekerjaan.

\section{Karakteristik Personal}

Karakteristik personal yang dimiliki oleh setiap manusia antara yang satu dengan yang lain betrbeda-beda. Robbins dan Judge (2014:46) mengemukakan bahwa karakteristik personal adalah cara memandang ke obyek tertentu dan mencoba menafsirkan apa yang dilihatnya mencakup usia, jenis kelamin, status perkawinan, dan masa kerja dalam organisasi. Karakteristik personal mencakup sifat-sifat berupa kemampuan dan ketrampilan, latar belakang keluarga, sosial, pengalaman, umur, kebangsaan, jenis kelamin, dan lainnya yang mencerminkan sifat demografis tertentu, serta karakteristik psikologis yang terdiri atas presepsi, sikap, kepribadian, belajar, dan motivasi (Winardi, 2004). 
Perawat yang profesional harus memiliki dan mampu menerapkan etika dan hal-hal yang telah tertuang dalam standar pelayanan keperawatan. Prinsip-prinsip profesi dan standar praktik pelayanan keperawatan yang profesional membutuhkan etika yang digunakan dalam menjalankan otonomi, keadilan, berbuat baik, jujur, tidak merugikan, menepati janji, menjaga rahasia, dan akuntabel.

Penelitian sebelumnya menunjukkan bahwa karakteristik personal berpengaruh positif dan signifikan terhadap komitmen organisasional (Haryanto \& Sriwidodo, 2009; Dwiningrum, 2015; Sancaya, 2017). Artinya, kepuasan menjadi harapan bagi individu ketika ia masuk dalam suatu organisasi dengan kondisi yang berbeda-beda, baik secara ekonomi maupun psikologi. Individu cenderung akan meninggalkan organisasi dan melepaskan diri menjadi bagian dari organisasi, jika harapannya tidak sesuai ketika mereka berada di dalam organisasi tersebut. Dalam hal ini, apabila karakteristik personal dalam diri karyawan dapat dipenuhi oleh organisasi, maka komitmen organisasional dalam diri karyawan juga tinggi. Oleh karena itu, dapat disimpulkan bahwa karakteristik personal memiliki kaitan dengan komitmen organisasional. Oleh karena itu, hipotesis pertama yang diajukan pada penelitian ini adalah:

$\mathbf{H}_{1}$ : Karakteristik personal berpengaruh positif terhadap komitmen organisasional.

\section{Karakteristik Pekerjaan}

Hackman dan Oldham (1975) mengatakan bahwa karakteristik pekerjaan merupakan sebuah model kontemporer yang penting tentang bagaimana mendisain pekerjaan. Dengan menggunakan lima karakteristik pekerjaan inti, para manajer dapat meningkatkan tiga keadaan psikologis kritis. Keadaan tersebut nantinya dapat meningkatkan variasi personal dan hasil kerja. Secara teori, karakteristik pekerjaan dapat dilihat melalui tiga sudut pandang, yaitu teori atribut tugas wajib, teori model karakteristik pekerjaan, dan model pemrosesan informasi sosial (Robbins \& Judge, 2014:270). Hasil penelitian sebelumnya menunjukkan bahwa komitmen organisasional dipengaruhi adanya tingkat variasi ketrampilan yang tinggi, identitas tugas, dan signifikansi tugas terhadap pekerjaan.

Pekerjaan yang mampu menunjukkan ketrampilan, kemampuan dalam menyelesaikan pekerjaan, serta kebebasan dan adanya umpan balik terhadap pekerjaan mereka akan lebih disukai oleh setiap pegawai, sedangkan pekerjaan yang cenderung monoton dan tidak memberi kesempatan kepada pegawai untuk mengeksplorasi kemampuannya akan mengakibatkan menurunnya komitmen organisasi bagi pegawai yang bersangkutan. Penelitian yang dilakukan oleh Djastuti (2011) dan Dwiningrum (2015) menunjukkan bahwa karakteristik pekerjaan mempengaruhi komitmen organisasi. Komitmen organisasi yang tinggi diperoleh dari adanya perpaduan lima faktor karakteristik pekerjaan yang mendorong pegawai untuk tidak meninggalkan organisasinya. Hubungan positif antara karakteristik pekerjaan dengan komitmen organisasional ditunjukkan dengan komitmen organisasional yang tinggi akan terlihat pada pegawai yang memiliki karakteristik pekerjaan yang baik. Demikian pula, jika karakteristik pekerjaan pegawai kurang diperhatikan, maka komitmen organisasional pegawai tersebut akan turun. Selanjutnya, hipotesis kedua yang diajukan pada penelitian ini adalah:

$\mathbf{H}_{2}$ : Karakteristik pekerjaan berpengaruh positif terhadap komitmen organisasional. 


\section{METODE PENELITIAN}

Penelitian ini menggunakan metode survei dengan menggunakan kuesioner yang harus diisi oleh responden. Populasi dalam penelitian ini adalah perawat rumah sakit di wilayah Gombong, Indonesia dan sampel penelitian ini adalah perawat berjumlah 75 orang yang diambil secara acak dengan teknik simple random sampling. Teknik pengumpulan data menggunakan kuesioner dengan skala Likert. Instrumen utama digunakan untuk memperoleh data yang disusun secara sistematis berisi beberapa pernyataan yang diberikan kepada responden yang telah memenuhi syarat validitas dan reliabilitas. Analisis data menggunakan regresi linier berganda dan pengujian hipotesis menggunakan uji signifikansi parsial. Berikut adalah model yang menjadi kerangka pemikiran dalam penelitian ini (Gambar 1).

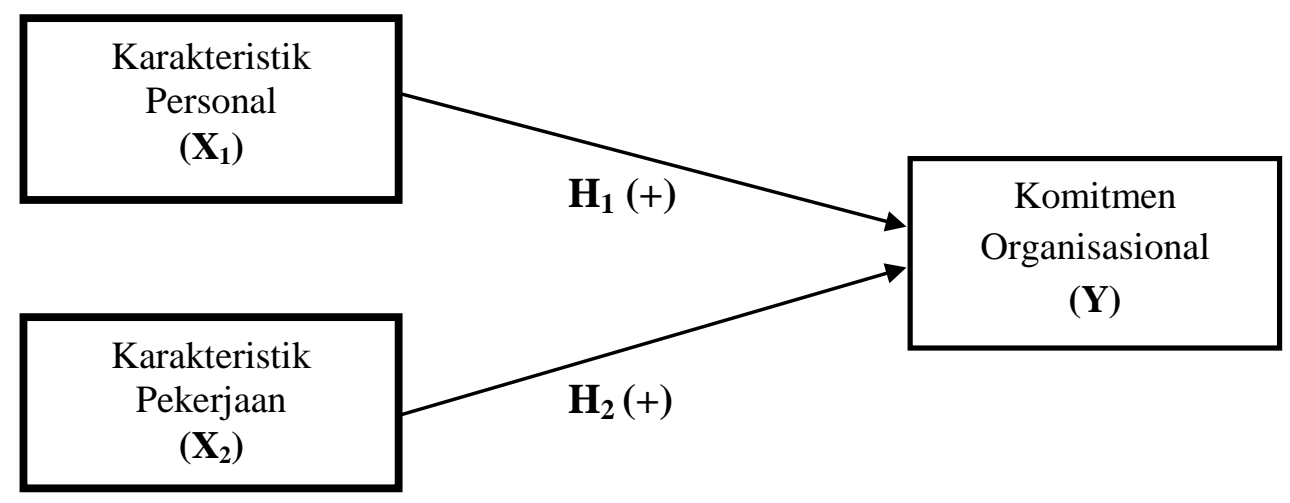

\section{Gambar 1. Kerangka Pemikiran}

\section{Definisi Operasional Variabel}

Menurut Mowday et al. (1979), komitmen organisasional adalah sesuatu yang melebihi kesetiaan pasif terhadap organisasi, melibatkan hubungan aktif dengan organisasi sedemikian rupa, sehingga individu bersedia memberikan sesuatu dari diri mereka sendiri untuk berkontribusi pada kesejahteraan organisasi. Tiga indikator komitmen yang dikembangkan oleh Mowday et al. (1979), adalah: keyakinan dalam penerimaan yang kuat terhadap tujuan dan nilai organisasi, kemauan untuk memberikan banyak usaha atas nama organisasi, dan keinginan kuat untuk mempertahankan keanggotaan dalam organisasi.

Robbins dan Judge (2014:46) mengemukakan bahwa karakteristik personal adalah cara memandang ke obyek tertentu dan mencoba menafsirkan apa yang dilihatnya. Menurut Robbins dan Judge (2014:46), karakteristik personal dapat diukur dengan beberapa indikator, yaitu: usia, jenis kelamin, status pernikahan, dan masa kerja. Menurut Hackman dan Oldham (1975), karakteristik pekerjaan merupakan suatu model kontemporer yang penting tentang bagaimana mendisain pekerjaan dengan indikator sebagai berikut: keragaman ketrampilan (skill variety), jati diri tugas (task identity), kepentingan tugas (task significance), otonomi (autonomy), dan umpan balik (feedback). 


\section{HASIL DAN PEMBAHASAN}

\section{Uji Analisis Regresi Linear Berganda}

Berdasarkan hasil perhitungan analisis data dengan menggunakan bantuan program SPSS dan alat analisis regresi linear berganda diperoleh hasil sebagai berikut:

Tabel 1. Hasil Uji Regresi Linear Berganda

\begin{tabular}{cccc}
\hline Variabel & $\begin{array}{c}\text { Standardized } \\
\text { Coeffisiens Beta }\end{array}$ & p-value (sig) & Keterangan \\
\hline Karakteristik Personal $\left(\mathrm{X}_{1}\right)$ & 0,187 & 0,018 & $\begin{array}{c}\text { Positif dan } \\
\text { signifikan }\end{array}$ \\
\hline Karakteristik Pekerjaan $\left(\mathrm{X}_{2}\right)$ & 0,708 & 0,000 & $\begin{array}{c}\text { Positif dan } \\
\text { signifikan }\end{array}$ \\
\hline
\end{tabular}

Sumber: Data primer diolah, 2018.

Berdasarkan hasil uji regresi linear berganda seperti tersebut dalam Tabel 1, model persamaan regresi diperoleh sebagai berikut:

$$
Y=0,187 X_{1}+0,708 X_{2}
$$

\section{a. Pengaruh karakteristik personal $\left(\mathbf{X}_{1}\right)$ terhadap komitmen organisasional $(\mathbf{Y})$}

Nilai koefisien regresi variabel karakteristik personal $\left(\mathrm{X}_{1}\right)$ adalah 0,187 (bernilai positif) dengan signifikansi sebesar 0,018 $(<0,05)$. Dari hasil tersebut menunjukkan bahwa $\mathrm{H}_{1}$ diterima yang berarti karakteristik personal berpengaruh positif dan signifikan terhadap komitmen organisasional perawat rumah sakit di Gombong.

\section{b. Pengaruh karakteristik pekerjaan $\left(\mathbf{X}_{2}\right)$ terhadap komitmen organisasional ( $\left.\mathbf{Y}\right)$}

Nilai koefisien regresi karakteristik pekerjaan $\left(\mathrm{X}_{2}\right)$ adalah 0,708 (bernilai positif) dengan signifikansi sebesar 0,000 $(<0,05)$. Dari hasil tersebut menunjukkan bahwa $\mathrm{H}_{2}$ diterima yang berarti karakteristik pekerjaan berpengaruh positif dan signifikan terhadap komitmen organisasional perawat rumah sakit di Gombong.

\section{Pembahasan}

Hasil pengujian dengan menggunakan uji analisis regresi linear berganda yang disajikan pada Tabel 1 menunjukkan bahwa variabel karakteristik personal memiliki nilai beta sebesar 0,187 dengan nilai signifikansi sebesar 0,018. Hasil ini menunjukkan bahwa karakteristik personal berpengaruh positif dan signifikan terhadap komitmen organisasional perawat rumah sakit di Gombong. Komitmen organisasional dari perawat rumah sakit yang ada di Gombomg akan bertambah seiring bertambahnya umur individu, jangka waktu bekerja pada organisasi, status pernikahan, dan juga jenis kelamin. Karena para perawat ini memiliki komitmen yang tinggi dan akan melihat dirinya sebagai karyawan yang berguna bagi organisasi dan berusaha sebaik mungkin demi kepentingan organisasi. Para perawat ini merasa keberadaan mereka di dalam sebuah rumah sakit sudah sesuai dengan yang diharapkan. Hal ini tentunya akan menimbulkan kepuasan yang baik, sehingga ia tidak akan meninggalkan rumah sakit dan komitmen organisasional dalam dirinya pun cukup tinggi. 
Hasil penelitian ini sesuai dengan pendapat Mowdey et al. (1982, dalam Luthans, 2015) yang mengatakan bahwa karakteristik personal merupakan salah satu faktor yang mempengaruhi komitmen organisasional. Pada penelitian ini menunjukkan bahwa perawat setuju apabila karakteristik personal dalam dirinya mempengaruhi adanya komitmen organisasional. Hasil penelitian ini juga mendukung penelitian sebelumnya yang dilakukan oleh Haryanto dan Sriwidodo (2009), Dwiningrum (2015), serta Sancaya (2017) yang menunjukkan bahwa karakteristik personal memiliki pengaruh positif dan signifikan terhadap komitmen organisasional.

Hasil pengujian dengan menggunakan analisis regresi linear berganda yang disajikan pada Tabel 1 menunjukkan bahwa variabel karakteristik pekerjaan memiliki nilai beta sebesar 0,708 dengan nilai signifikansi sebesar 0,000. Hasil ini menunjukkan bahwa karakteristik pekerjaan berpengaruh positif dan signifikan terhadap komitmen organisasional perawat di rumah sakit di wilayah Gombong. Komitmen organisasional perawat di wilayah Gombong ini akan meningkat apabila karakteristik pekerjaan yang diberikan rumah sakit sudah sesuai dengan karakteristik pekerjaan yang diharapkan oleh perawat. Aspek pekerjaan perlu diperkaya melalui pemberian variasi ketrampilan untuk melakukan pekerjaan, identitas tugas, signifikansi tugas, otonomi, serta umpan balik. Ketika perawat diberi kebebasan dalam menentukan cara melakukan pekerjaan di rumah sakit, mereka akan merasa lebih dihargai karena diberikan tanggung jawab penuh terhadap pekerjaan mereka. Hal tersebut akan menimbulkan dorongan yang kuat bagi perawat untuk tetap menjadi bagian dari rumah sakit dan menunjukkan komitmen organisasional yang tinggi.

Hasil penelitian ini sependapat dengan Robbins dan Judge (2014:270) yang mengemukakan bahwa individu hanya dapat dimotivasi untuk bekerja lebih baik dan meningkat kepuasannnya, jika ada karakteristik pekerjaan yang memuaskan. Adanya keberagaman tugas yang diberikan, identifikasi terhadap tugas melalui kesempatan untuk mengerjakan tugas dari awal sampai akhir, memberikan otonomi dengan memberikan kebebasan untuk menentukan sendiri prosedur kerjanya ternyata dapat berpengaruh positif terhadap komitmen organisasional. Penelitian ini menunjukkan bahwa perawat memberikan persepsi yang cukup baik terhadap karakteristik pekerjaan yang diberikan oleh rumah sakit. Hasil penelitian ini mendukung penelitian sebelumnya yang dilakukan oleh Djastuti (2011) dan Dwiningrum (2015) yang menyatakan bahwa karakteristik pekerjaan berpengaruh positif dan signifikan terhadap komitmen organisasional.

Berdasarkan hasil penelitian ini, pihak rumah sakit yang ada di wilayah Gombong harus lebih memperhatikan faktor-faktor yang dapat mempengaruhi komitmen organisasional ke depannya, terutama karakteristik pekerjaan yang diterapkan pada perawat. Aspek karakteristik pekerjaan perawat dapat ditingkatkan melalui kegiatan disain kerja atau redisain kerja yang lebih tepat. Cara yang bisa dilakukan, yaitu job rotation (rotasi kerja), job enrichment (pengayaan pekerjaan), dan job enlargement (perluasan pekerjaan) yang sesuai dengan posisi masing-masing pekerja-an perawat. Kepercayaan menjadi sesuatu yang penting ketika perawat diberikan otonomi dalam menyelesaikan pekerjaannya. Mereka akan merasa dihargai ketika mendapatkan masukan-masukan positif dan membangun terhadap hasil kerjanya. Kondisi yang demikian ini akan mendorong perawat untuk bekerja melampaui dari apa yang diharapkan oleh rumah sakit, sehingga keinginan mereka untuk keluar dapat dihindari seoptimal mungkin. Oleh karena itu, variabel karakteristik personal dan karakteristik 
pekerjaan yang sesuai akan menghasilkan kepuasan di dalam diri perawat. Selanjutnya, komitmen organisasional perawat pun akan meningkat.

\section{KESIMPULAN}

Komitmen organisasional menjadi faktor penting bagi perawat dalam melakukan kegiatan pelayanan di rumah sakit. Hasil penelitian ini menunjukkan bahwa karakteristik personal dan karakteristik pekerjaan merupakan dua variabel penting yang mempengaruhi komitmen organisasional perawat rumah sakit di wilayah Gombong. Penelitian ini juga menunjukkan bahwa karakteristik pekerjaan memiliki pengaruh lebih besar terhadap komitmen organisasional daripada karakteristik personal.

Selanjutnya, hasil penelitian ini menjadi bukti empiris untuk bidang dan topik yang relevan dengan penelitian ini. Untuk penelitian mendatang, ruang lingkup variabel atau obyek yang diteliti dapat diperluas agar mampu meningkatkan daya generalisasi penelitian. Ada pun perluasan untuk melengkapi penelitian ini dapat mencakup variabel-variabel bebas lain di luar penelitian ini dengan jumlah responden yang lebih besar.

\section{DAFTAR PUSTAKA}

Azwar, A. (2011). Pengantar Administrasi Kesehatan. Tangerang: Binarupa Aksara.

Bakibinga, P. (2012). The Experience of job Engagement and Self-care among Ugandan Nurse and Midwives. Dissertation. Africa University of Berge.

Budiono. (2016). Kosep Dasar Keperawatan. Jakarta.

Chen, S., Wu, W., Chang, C., Lin, C., Kung, J., Weng, H., Lin, Y., \& Lee, S. (2015). Organizational Justice, Trust, and Identification and Their Effecs on Organizational Commitment in Hospital Nursing Staff. BMC Health Services Research, 15(363), 1-17.

Djastuti, I. (2011). Pengaruh Karakteristik Pekerjaan terhadap Komitmen Organisasi Karyawan Tingkat Managerial Perusahaan Jasa Konstruksi. Universitas Diponegoro.

Dwiningrum, N. R. (2015). Pengaruh Karakteristik Personal dan Karakteristik Pekerjaan terhadap Komitmen Organisasi (Studi kasus pada Politeknik Negeri Balikpapan). Skripsi (tidak diterbitkan). Balikpapan: Politeknik Negeri Balikpapan.

Hackman, J. R. \& Oldham, G. R. (1975). Development of The Job Diagnostic Survey. Journal of Applied Psychology, Vol 60, 159-170.

Haryanto, T. \& Sriwidodo, U. (2009). Pengaruh Karakteristik Personal, Karakteristik Kerja dan Pengalaman Kerja terhadap Komitmen Organisasi. Skripsi (tidak diterbitkan). Surakarta: Universitas Slamet Riyadi Surakarta.

Lee, S.P., Chitpakdee, B., \& Chontawan, R. (2011). Factors Predicting Organizational Commitment among Nurses in State Hospitals, Malaysia. International Journal of Organizational Analysis, 19(2), 146-170.

Luthans (2015). Perilaku Organisasi. Edisi Sepuluh. Yogyakarta: Andi Offset.

Mowdey, R. T., Steers, R. M., \& Porter, L. W. (1979). The Measurement of Organizational Commitment. Journal of Vocational Behavior, Vol 14. h. 224-227. 
Muliana, S. (2013). Faktor-faktor yang Mempengaruhi Keinginan Pindah Kerja Perawat Rumah Sakit Atma Jaya. Tesis. Universitas Esa Unggul. 99 hal.

Mulyono, W. A. (2010). Hubungan Spiritualitas di Tempat Kerja (STK) dengan Komitmen Organisasi Perawat di Rumah Sakit Islam Fatimah Cilacap. Tesis. Depok. Program Magister Keperawatan Universitas Indonesia. 150 hal.

Robbins, S. P. \& Judge. T. A. (2014). Perilaku Organisasi. Edisi ke-14. Jakarta: Salemba Empat.

Sancaya, I. G. N. W. (2017). Pengaruh Karakteristik Personal dan Karakteristik Pekerjaan terhadap Komitmen Organisasi karyawan Pengrajin Kain tenun Endek di Pelangi Traditional Weaving Sidemen. Bali: Universitas Pendidikan Ganesha.

Siregar, I. N. A. (2015). Faktor-faktor yang Berhubungan dengan Keinginan Pindah Kerja (Turnover Intention) Perawat di Rumah Sakit Sehat Terpadu DD Tahun 2014. Skripsi. Jakarta: Universitas Islam Negeri Syarif Hidayatullah. 131 hal.

Siswanto, H. B. (2013). Pengantar Manajemen. Jakarta: PT. Bumi Aksara.

Triatna, C. (2015). Perilaku Organisasi dalam Pendidikan. Bandung: PT Remaja Rosdakarya.

Widyani, E. (2014). Hubungan Karakteristik Kepala Ruangan dengan Produktivitas Kerja Perawat Pelaksana di Ruang Rawat Inap RSI Ibnu Sina Padang. Skripsi. Padang: Fakultas Keperawatan Universitas Andalas.

Winardi (2004). Manajemen Perilaku Organisasi. Cetakan Kedua. Jakarta: Kencana Prenada Media Group.

Yanidrawati, K., Susilaningsih, F. S., \& Somantri, I. (2011). Hubungan Kepuasan Kerja dengan Kinerja Perawat di Ruang Rawat Inap Rumah Sakit Umum Daerah Kabupaten Bekasi. 